Meta

Journal des traducteurs

Translators' Journal

\title{
Kinds of Ambiguity: Reflexions on English Translations of Japanese Verse
}

\section{A. J. Pinnington}

Volume 33, numéro 1, mars 1988

Traduction et interprétation au Japon

Translation and Interpretation in Japan

URI : https://id.erudit.org/iderudit/003838ar

DOI : https://doi.org/10.7202/003838ar

Aller au sommaire du numéro

Éditeur(s)

Les Presses de l'Université de Montréal

ISSN

0026-0452 (imprimé)

1492-1421 (numérique)

Découvrir la revue

Citer cet article

Pinnington, A. J. (1988). Kinds of Ambiguity: Reflexions on English Translations of Japanese Verse. Meta, 33(1), 50-63. https://doi.org/10.7202/003838ar d'utilisation que vous pouvez consulter en ligne.

https://apropos.erudit.org/fr/usagers/politique-dutilisation/ 


\title{
KINDS OF AMBIGUITY : REFLECTIONS ON ENGLISH TRANSLATIONS OF JAPANESE VERSE
}

A.J. PINNINGTON

Ferris Women's College, Yokohama, Japan

Among the 1978 lyrics included in the great medieval anthology of Japanese verse, the Shin Kokinshu, we find the following poem by Fujiwara Teika (1162-1241) :

\author{
Shirotae no \\ sode no wakare ni \\ tsuyu ochite \\ mi ni shimu iro no \\ akikaze zo fuku. (No 1336)
}

Let us compare two English translations of this poem ; the first is by the indefatigable Japanese translator H.H. Honda :

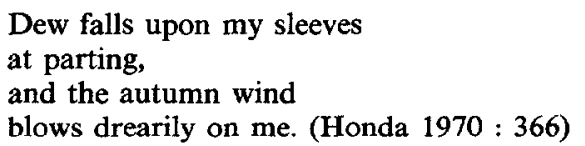

This surely looks just the way most English readers expect a Japanese poem to look : brief, sensitive, fragmentary, understated. It is not quite a literal translation of the original ; "shirotae" ("white hemp") and "iro no" ("the colour") have been omitted. Otherwise it reflects accurately enough the surface meaning of the original. This style of translation I propose to call the "minimalist" style.

The second translation of the poem is one by Robert Brower and Earl Miner, given in their magisterial study Japanese Court Poetry :

The white sleeves covering us

Glisten with the dew and, brightened by our tears,

Are parted by the light of dawn;

And as we dress are shaken by the autum wind,

Which blows its color through our anguished hearts. (Brower and Miner 1961 : 317)

Here nothing in the original has been omitted, but a great deal has been added : "glisten", "brightened by our tears", "by the light of dawn", "as we dress", and "anguished". Most, although not all, of these ideas are clearly implicit in the original. This style of translation I propose to call, for obvious reasons, the "maximalist" style of translation. 
As another example, let us take two translations of the most famous haiku by Matsuo Basho (1644-94) :

Furuike ya

kawazu tobikomu

mizu no oto.

The first translation was made by an English-language haiku poet, William J. Higginson :

old pond...

a frog leaps in

water's sound. (Higginson $1985: 9$ )

This is clearly a translation in the "minimalist" style ; it also happens to be completely literal (although the awkwardness of the inversion in the final line has no counterpart in the Japanese). Again, this translation is what we have come to expect of a haiku: it is brief, colloquial and vivid. Contrast it with the following translation in the "maximalist" style by Nobuyuki Yuasa :

Breaking the silence

of an ancient pond,

A frog jumped into water -

A deep resonance. (Yuasa $1966: 9)$

Once more, much has been added : "Breaking the silence" and "A deep resonance", while "the sound of (water)" has been omitted. Yuasa would almost certainly argue that all of these ideas are in some sense implicit in the original, and be supported in his claim by many Japanese critics.

When faced with two translations of the same poem which differ as much as those in the examples do, what should our response be ? Certainly the "minimalist" style has won most favour from ordinary readers, and perhaps even come to define for many people the special contribution of Japanese verse to world literature; but is this the most appropriate style of translation? In this paper I wish to explore the problems raised by the presence of these two very different styles of translating Japanese verse, both for their intrinsic interest, and for the questions they raise about translation in general.

It is sometimes felt that the problems associated with literary translation have played far too large a part in translation theory, literary translation being in important ways unrepresentative of translation in general. While I think that there is some truth to this claim, it seems to me that it is not entirely accidental that those engaged in literary translation have contributed so much to general reflection on the subject. This is because the literary translator faces in an extreme way the double demand which is placed to some degree on every translator : the need at once to be faithful to the original work, and to produce something which "works" in the target language (just what is involved in "working" will depend on the kind of translation involved). There will always, however, be a certain gap between these two demands precisely because languages are different, and this gap will reproduce itself at every level, from the sentence to the rhetorical and logical organization of the work as a whole (see Bassnett-McGuire 1980 for a discussion of this latter aspect of literary translation). Every translator is to some degree tugged in different directions by these two demands, and the work of translation is, in part, a continuous series of judgements as to how they are best reconciled. At the same time, however, most translators lean in one direction or the other ; those who give proportionately more weight to the demand for fidelity engage in what we might call translation as 
knowledge, that is, knowledge of the original work, and are less concerned that their translations work effectively on their own. The extreme instance here is the crib, designed purely to help a student understand the original. Translators who are more concerned about producing something which will give satisfaction in its own right will engage in what might be termed translation as creation; the extreme instance here, in literary terms, is the "imitation", in which a theme or argument from a foreign writer is adapted to express the translator's own vision of the world. Academics will typically engage in the former kind of translation; poets in the latter.

Although these two divergent tendencies can be recognized and named, all translators nevertheless will feel to some extent the need to satisfy both demands. In more practical contexts, however, the problems which this double demand generates tend to be disguised by the clarity of the criteria for the translation's success. When some concrete request or information is being translated, then the translator quickly discovers whether he is fulfilling the demands of his work or not. In cases of literay or religious translation, by contrast, the question of success is much less straightforward, and this is perhaps why reflection on literary and religious translation has contributed so much to translation theory. In both these kinds of translation, not only is it very difficult to define clearly what counts as success, but also the criteria for success continually alter. Nothing dates as rapidly as translations of verse ; as poetic fashions change, new translations of verse are produced.

This essential difficulty is exacerbated enormously in translation between remote languages and cultures. Indeed, one major weakness of much translation theory is that it is concerned exclusively with translation between the major European languages. Although translation between any two languages raises profound problems, from the perspective of an "exotic" language such as Japanese, it is clear that the work of the translator between European languages is made less complex by the linguistic structures and cultural expectations common to the linguistic communities. Translating totally alien linguistic structures and totally alien cultural forms widens the gap between translation as knowledge and translation as creation to the point that the conscientious translator must despair of ever achieving a fully satisfactory translation.

Having emphasized the difficulties facing the translator of Japanese poetry, however, it must be admitted that, on the face of it, the history of the translation of Japanese poetry into English represents a signal success story. When we look at the remarks of early scholars writing about Japanese poetry, it is striking just how negative their views are. W.G. Aston, for example, wrote in his pioneering $A$ History of Japanese Literature (1899) that "narrow in its scope and resources, it (Japanese poetry) is chiefly remarkable for its limitations - for what it has not, rather than for what it has" (Aston 1972 : 24), and he added, on the subject of haiku, that "it would be absurd to put forward any serious claim on behalf of Haikai to an important position in literature". This is not to say that Aston found Japanese verse valueless, but merely that he took for granted its inferiority as a whole to European poetry. A similar sense of dissatisfaction can be seen in the great Victorian scholar of Japanese, B.H. Chamberlain, who remarked of the tanka, in his Japanese Things (1905), that "the narrow bounds of the thirty-one syllable form contributed to the same undesirable end. It contributed doubly, - on the one hand by enabling everybody to say something in verse, on the other by making it well-nigh impossible for even the truest poet to say anything of value" (Chamberlain $1971: 376$ ). Contrast with this the contemporary enthusiasm of the poet and translator. Kenneth Rexroth :

It can safely be said that classical Japanese and Chinese poetry are today as influential on American poetry as English or French of any period, and close to determinative for those born since 1940. I have tried to explain why this is so. Classic Far Eastern poetry speaks for 
all those elements of a complete culture, or factors of the human mind, of man at his most fulfilled, which are suppressed or distorted by Western civilization. (Rexroth 1973 : 157 ; see also Kodama 1984 : 121)

Rexroth's remarks here are undoubtedly somewhat exaggerated, yet there is clearly a profound gulf between his view of Japanese poetry and that of Aston or Chamberlain. Certainly many cultural factors, besides those of a purely literary nature, lie behind this shift in opinion. Even today, however, the average American poet is more likely to be able to read English or French poetry in the original than Japanese or Chinese. This powerful oriental influence must therefore be conveyed chiefly by means of translation.

While few writers would go so far as to suggest that this shift in critical opinion directly reflects the impact of Japanese poetry alone (although see Miner 1958), it is widely held that the triumph of modernist notions of poetry has allowed modern Western readers genuine access to traditional Japanese poetry. J. Thomas Rimer and Robert E. Morrell, for example, comment that :

If early apprehensions of Japanese poetry were filtered through the Victorian sensibilities of Americans and Europeans whose idea of poetry came from the reading of Longfellow, Tennyson, Hugo, and Heine, evolution of poetry in our centry, from Pound to Ferlinghetti, has prepared our sensibilities to understand better the nature of the particular poetic truth that the various manifestations of Japanese poetry possess. (Reimer and Morrell $1975: 13$ )

As with the reception of many other aspects of Japanese culture, Japanese verse has thus come to bear the paradoxical quality for Westerners of being at once archaic and modern, exotic and up-to-date (see Hoover 1978). In terms of the two schools of translation referred to above, this shift has also by and large reflected the triumph of the minimalist mode of translation ; Donald Keene, in his widely influential Japanese Literature : An Introduction for Western Readers (1955), wrote of the connection between the haiku and the imagists :

Slim volumes with such revealing titles as Pictures of the Floating World and Japanese Prints indicate how congenial these poets found the haiku, and although the main thesis of this school, that poetic ideas are best expressed by the rendering of concrete images rather than by comments, need not have been learned from Japanese poetry, it is hard to think of any other poetic literature which so completely incarnates this view. (Keene $1955: 46$ )

Thus we have the odd paradox that, in the case of Japanese poetry, translation as creation has largely coincided with a literal, minimalist style of translation, just the opposite of what one might expect.

This optimistic view of the matter, emphasizing the role of the Imagists in opening our eyes to the true value of Japanese poetry, has had a deep influence upon translators. Here, however, while accepting that this version of events has a kernel of truth, I would like to raise some doubts concerning it, and suggest that Japanese poetry was in fact kidnapped by the Modernists, and that one false exoticism was replaced by another. Certainly, there can be no doubt that the poetics of Victorian Romanticism left early scholars ill-equipped to appreciate Japanese poetry. One cause of dissatisfaction was the brevity and the emotional impressionism of most Japanese verse, which seemed to disqualify it from serious consideration. (Thus the word haiku was translated by both Aston and Chamberlain as "epigram", not one of the major poetic forms in the European tradition). Another point which perturbed these critics was the deep conventionality of Japanese poetry : in the words of Aston, "the composition of Tanka has been for centuries little more than a mere mechanic art" (Aston 1972:32). This repugnance at the ease with which tanka and haiku were written does indeed reflect a 19th century concern 
with poetic "sincerity" ; by the standards of Wordsworth and Tennyson, it was naturally difficult to judge most Japanese poetry as anything but trivial. Some strain is often evident in Victorian translations of Japanese verse, such as those of W.N. Porter :

Stillness

Into the calm old lake

A frog with flying leap goes plop!

The peaceful hush to break! (Hiroaki Sato $1983: 151$ )

In its sentimental diction and title, its wordiness, and its use of rhyme, this clearly represents a rather desperate attempt to assimilate the deeply alien mode of haiku to Victorian poetics. (It is worth remarking, however, that the doubts of Victorian scholars concerning the value of tanka and haiku were also felt by many Meiji-period Japanese, following the shock of exposure to European culture, and that this period saw a profound revaluation and redefinition of their own poetic tradition by leading Japanese writers (see Beichman 1986 : 12-14). Moreover, this "Victorianising" mode of translation into English is still often followed by the Japanese themselves (see, for example, Miyata 1981).

Yet, while Victorian translations do often seem to be working against the grain of the original, this is not to concede the claims of the Modernists. For while they did indeed effect a revaluation of the claims of short, impressionistic poems, they were even more hostile to conventional poetic diction than their Victorian forebears. This, I would contend, produced a different and a more subtle distortion of Japanese poetry. It is certainly true that Japanese poetry played a part in the ferment of ideas which emanated from T.E. Hulme and the poet's club and which finally issued in Imagism; F.S. Flint recalled : "We proposed at times to replace it (poetry) by pure vers libre; by the Japanese tanka and the haikai; we all wrote dozens of the latter as an amusement ... by rimeless poems like Hulme's Autumn, and so on ... We were very much influenced by modern French symbolist poetry" (quoted by Miner 1958 : 100.)

What is chiefly striking about this amateur interest in Japanese poetry, however, is that those concerned, unlike worthy scholars such as Aston or Chamberlain, had no knowledge of Japanese whatsoever. They were thus totally dependent on translations and from these translations they gained various misapprehensions concerning it. The most obvious of these is their apparent assumption that all Japanese verse was in "vers libre" (the struggle for "vers libre" being an important part of the battle over poetic style and diction). Thus these poets rapidly formed an idea of what Japanese verse should be, and they were not at all shaken by reports to the contrary. This comes out especially clearly in F.S. Flint's 1908 review of a book of translations of tanka :

It is a pity, however, that the translators did not choose some other measure than the heavy English rhymed quatrain. It is probable that nearly all the spontaneity of the Japanese tanka has thus been lost. The Japanese, we are told, are quick to take an artistic hint ... "to them in poetry as in painting, the half-said thing is dearest" - the suggestion not the complete picture (one thinks of Stéphane Mallarmé) ... I could have wished that the poems in this book had been translated into little dropping rhythms, unrhymed... To the poet who can catch and render, like these Japanese, the brief fragments of his soul's music, the future lies open ... he must write, I think, like these Japanese, in snatches of song. The day of the lengthy poem is over, - at least for this troubled age... (Pondrom 1974 : 50-51)

The assimilation of the Japanese lyric to the aesthetics of Symbolism could not be clearer ; undeterred by his ignorance of the original, Flint does not hesitate to criticize the (Japanese) translators for betraying its spirit by using rhyme - it does not occur to 
him that there may be artistic reasons for their choice of a formal verse style. It is clear that Japanese verse is being forcibly enlisted in a struggle against Victorian poetics which is utterly unrelated to its own real literary qualities. It is being transformed into an anticipation of the subjectivist poetics of early 20 th English poetry : "the brief fragments of his soul's music". The obvious exoticism of the Victorian translation has been replaced by the more subtle, and hence more insidious, exoticism of Modernism.

We find just the same sort of Symbolist reading of Japanese poetry in Ezra Pound's famous and influential account of his own composition of a haiku :

Three years ago in Paris I got out of a "metro" train at la Concorde, and saw suddenly a beautiful face, and then another and another, and then a beautiful child's face, and then another beautiful woman, and I tried all that day to find words for what this had meant to me, and I could not find any words that seemed to me worthy, or as lovely as that sudden emotion... I found, suddenly, the expression. I do not mean that I found words, but there came an equation ... not in speech, but in little splashes of colour... The Japanese have had the sense of exploration. They have understood the beauty of this sort of knowing. A Chinaman said long ago that if a man can't say what he has to say in twelve lines he had better keep quiet. The Japanese have evolved the still shorter form of the haiku.

The fallen blossom flies back to its branch A butterfly

This is the substance of a very well known haiku... The "one image poem" is a form of superposition, that is to say it is one idea set on top of another... I wrote a thirty-line poem, and destroyed it because it was what we call work "of second intensity". Six months later I made a poem half that length; a year later I made the following haiku-like sentence.

The apparition of these faces in the crowd :

Petals on a wet, black bough.

I dare say it is meaningless unless one has drifted into a certain vein of thought. (Sullivan $1970: 51-54)$

Again the haiku is identified with an image which expresses, in a somewhat mysterious, Symbolist fashion, a certain ineffable state of mind - "an intellectual and emotional complex in an instant of time", as Pound's famous definition of the "image" runs. This is clearly an understanding of Japanese poetry which would very definitely insist upon the need for a "minimalist" style of translation; yet, as in Flint, and as later with Chinese culture, Pound is press-ganging Japanese verse into his own poetic struggle. (It is noteworthy that Imagism was initially linked not with the Orient but with that other poetry beloved of Modernists, classical Greek - see Jones 1972 : 18.)

Just how misleading such a view of Japanese poetry can be is amusingly shown by the haiku which is quoted by Pound in support of his view of the Japanese tradition, and which is also quoted, in a slightly different form, by F.S. Flint. This haiku was, by some quirk of cultural history, widely known as the representative haiku in the West until the Second World War, and was very widely translated and cited in books on Japanese verse (see Kazuo Sato 1980 : 34). Yet, as Hiroaki Sato has explained, the haiku is far from being a moment of vision; rather it is a witty parody of a well-known Buddhist proverb : "A fallen blossom doesn't return to its branch" (Hiroaki Sato 1983 : 73) ; the correct explanation was in fact available in Lafcadio Hearn's Japanese Lyrics (1915: 83). In other words, not only is the haiku a good example of the kind of irreverence long associated with the form, but, even more important, it is a poem that can only be understood with some knowledge of the Japanese context. Many Western devotees of haiku may prefer the poem in the Poundian form - but what they would be preferring is Found to the original poem itself. 
What is lost in this "subjectivist" account, in fact, is precisely the conventional and traditional nature of Japanese poetry which, together with the delight in word play, so repelled Victorian critics. But, whereas these critics honestly faced the difficulty which the remoteness of the Japanese conception of poetry presents to Western sensibilities, the Modernists surmounted this difficulty by ignoring it (or by their ignorance of it). This itself, however, raises a deep problem about the Poundian "revolution" in poetic translation, a shift in ways of thinking about literary translation which has had a wide impact on translation theory. George Steiner, an enthusiastic supporter of the Poundian approach, has summed up this "revolution" very concisely :

What he revolutionized was the idiom of translation, the notion of what a translation is and of how it relates to the original... Pound's translations ... are re-enactments of the original poetic deeds in the cadence, tonality, idiomatic stress of the modern. The translation exacts from the original the utmost of felt relevance ; it carries to the extreme Kierkegaard's dictum, "it is not worthwhile remembering that past which cannot become present". (Steiner $1966: 37)$

This is emphatically a defense of "translation as creation" - yet, it also tends to elevate subjectivism into a principle. The apparent openness to alien cultural traditions of the Poundian tradition conceals a deeper willingness to reduce all poetry to its own late. If the only past we can have is that which can be made present, then in practice we can have no past at all. Here the subjectivism of Pound's view of literature appears at its most exposed. The deep conventionality, the wit, the word-play, the formality, the allusiveness of Japanese poetry (many of the very qualities which have traditionally defined poetry in Japan) must be resolutely ignored. In a sense, of course, a virtue is being made of necessity, and many attractive poems are being created in the process. Yet the thinness of such translation is evident. This is amusingly illustrated by the opportunism of the publisher of a collection of Lafcadio Hearn's translations of Japanese poetry issued in 1915 :

The reader will understand that as the poets relied for their effect largely upon the opportunities for subtle and intricate double-meanings afforded by the peculiar structure of the Japanese language, it is scarcely possible to do them justice in an alien tongue... Indeed, in many cases the elaborate plays upon words are too involved to be susceptible of explanation.

In their limitation of a poem to the presentation of a single impression and in their ability to present that impression with the utmost vividness and with the sternest economy of words, these Japanese poets are strangely akin to the Imagists, the youngest of the modern schools. (Hearn 1971 : vii-viii)

It is, of course, precisely because the "subtle and intricate double-meanings" cannot be translated that the poems ends up so "strangely" akin to the work of the Imagists : the failure of the translation is the success of the poet. (It is worth noting that similar criticisms of Poundian translations of the classics were made by the literary critic C.S. Lewis - see Green and Hooper 1974 : 293-294.)

Kenneth Rexroth is himself a good example of a well known translator professing Poundian principles. According to Rexroth :

One of the great troubles with the widespread appreciation of Japanese verse has been the vulgarity of most translators, especially those who have found it necessary to use rhyme. Japanese poetry is, like that of Mallarmé ... a poetry of sensibility. In the hands of a literary oaf sensibility turns instantly into sentimentality just as subtle verse turns to doggerel. (Rexroth 1970 : 95) 
Here is the authentically Poundian note of contempt for the "literary oaf", as well as the tendency to see Japanese verse in Symbolist terms. Thus it is not surprising to find Rexroth saying of his own translations :

... there is a certain amount of inconsistency in degree of literalness. Over the years the relationship to the Japanese poem was always a personal and creative one, and in some cases the mood of the moment led me to develop slightly certain implicits or suppress certain obvious explicits. Hardly ever are there many more syllables in the English poem than in the Japanese original, and in ninety out of a hundred examples the translation is as accurate and brief as I could manage. I have never tried to explain away the poem, to translate the elusive into the obvious, as has been, unfortunately, so often the case with translators from the Japanese in the past... (Rexroth 1964 : xix)

Here is an excellent example of the coincidence of a "minimalist" approach with "translation as creation" in the modern translation of Japanese poetry. Rexroth's hostility to "explaining" the original clearly derives from his Modernist conception of Japanese poetry as a poetry of elusive, mysterious images. Yet, can such translations really be said to convey the original to the reader ? To take an example of a fairly literal Rexroth translation, we have the following :

Deep in the mountain,

Trampling the red maple leaves,

I hear the stag cry out

In the sorrow of Autumn. (Rexroth $1964: 70$ )

The original, by Sarumaru Daifu (date unknown), is to be found in the Kokin Wakashu (n० 215) and in Fujiwara Teika's well known anthology, the Hyakunin Isshu $\left(n^{\circ} 5\right)$ :
Okuyama ni
momiji fumiwake
naku shika no
koe kiku toki zo
aki wa kanashiki

(Especially when I hear the cries of the deer, deep in the mountains, treading the autumn leaves, then the autumn is sad.)

Rexroth's minimalist version has, in fact, less syllables than the original ; correspondingly, he has omitted one important idea from the poem : "kiku toki zo" "when I hear (the crying of the deer)" (this "when" is strongly emphasized by the particle "zo", "especially"). In fact, Rexroth has transformed the original poet's reflection on nature into the expression of an immediate experience, and this serves to obscure the symbolic function of the deer, which in the translation becomes merely an example of an image in the Poundian sense, "an intellectual and emotional complex at an instant of time".

In actuality, as Japanese editors remark, the cries of the stags in autumn were thought to express their longing for their absent mates (see, for example, Manyoshu, $\mathrm{n}^{\mathrm{o}}$ 2146, Shin Kokin Wakahu, $\mathrm{n}^{\circ} 446$ ). Thus the point of the poem is precisely its conventionality ; the reference to a shared courtly understanding of the significance of nature allows the deer to function as a symbol of the poet's own loneliness, something which confirms the traditional perception of autumn as a time of sadness. There is nothing elusive, mysterious or fragmentary about the poem ; rather its pleasure comes from its confirmation of feelings shared by poet and audience. In this respect it is precisely the opposite of the ubiquitous "making strange" of Modernist poetry. Rexroth's translation has a certain power as a poem, but this power has little to do with that of the original. 
In this kind of case, is there really any alternative to explanation? A translation like that of Rodd and Henkenius probably conveys to us much more of the original :

treading through the

autumn leaves in the deepest

mountains I hear the

belling of the lonely deer -

then it is that autumn is sad. (Rodd and Henkenius $1984: 109$ )

By adding "lonely" and thus "explaining" the image, they bring us far closer to the actual meaning of the original. On the other hand, McCullough's translation brings out the significance of the grammatical structure of the original more clearly :

The gloom of autumn

Strikes sharpest into our hearts

When we hear a stag

Calling as he presses through

Colored leaves deep in the hills. (McCullough $1985: 55$ )

Although McCullough has certainly paraphrased the original, it is clear that this paraphrase is at the service of the meaning of the original poem. Although these translations may be much less successful as English poems, are they not more responsible translations? As McCullough herself has written :

Two basic options exist for the translator of classical Japanese poetry. A waka may be treated as a point of departure for a very different poem in another language, or an effort may be made to reproduce content, form, and tone as faithfully as possible. The second method, which seems more conducive to an understanding of Japanese literature, has been the one adopted here. Unfortunately, it has not produced many poems in English. (McCullough 1985 : vi)

In fact, faced with the complexities of classical Japanese poetry, one rapidly concludes that truly satisfactory verse-translations are simply not possible. Carmen Blacker has brilliantly described something of the verbal complexity of the tanka in the following terms :

We should remember too that in these short songs many words are like shot silk. They flash red or green or even blue as we move. The same sound refracts into two, three or several meanings, so that the poem reaches out further than the shortness of its span might imply. Other words are like heralds announcing the coming of another. Others, again, have relationships built into the structure of their meaning : we know when one appears that the other cannot be far off. All of which hints that the thirty-one syllables are but an inner core surrounded by unspoken, yet powerful circles of images. (Blacker, Introduction, Waley 1976 : vii)

Here, not only are the main verbal conventions of classical verse explained clearly, but Blacker also touches upon a deeper issue : that the brevity of the classical form is only superficially akin to the brevity of much Symbolist verse. For the brevity is transcended not only by the sublety of the word-play, but also by the way the poems are so closely integrated into a whole tradition of thought and feeling that the individual poem is not necessarily the most suitable unit for appreciation. (This issue has been recently discussed in slightly different terms by Miner - see Miner 1985 : Chapter One.)

In view of such considerations, it is clear that the notion of Modernist poetics allowing us an access to classical Japanese poetry denied to the Victorians is something of an exaggeration. To take one example of a widely translated poem which demands at 
the least a "maximalist" translation, there is one of the most famous poems of Ono no Komachi (fl. ca. 833-857) :

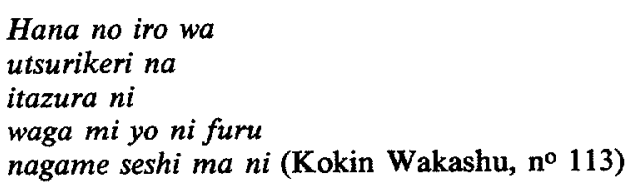

The verbal complexity of the lyric here is such that the same sounds in a sense contain a variety of different poems. The point is not, however, as Tom Galt claims in his excessively "creative" translation of the Hyakunin Isshu, that "The abundant puns and words with extra overtones often make four or five quite dissimilar translations of one tanka" (Galt 1982 : xii), because the poem itself means all these different poems at once. Thus "Hana no iro wa/utsurinikeri" means both "the colour of the blossoms has faded" and "my looks have faded", and "waga mi yo ni furu/nagame seshi ma ni" means both "while the long rains fell" and "while I was lost in thoughts (of love) and my body grew old". In the face of this complexity, one Japanese editor has offered a modern Japanese paraphrase which may be translated as follows :

Already both the colour of the blossoms and my own beauty have completely faded. Come to think of it, I have become utterly old and frail without gaining anything, absorbed in haughty thoughts of love and merely looking on life, just as the blossoms have been completely scattered by the long rains of spring. (Ozawa $1971: 97$ )

In the face of such complexity, it is clear that Rexroth's "minimalist" translation of the poem is deeply inadequate to the original :

As certain as color

Passes from the petal,

Irrevocable as flesh,

The gazing eye falls through the world. (Rexroth $1964: 45$ )

Not only has the central comparison between the fate of the blossoms in the spring rain and the loss of beauty in a life spent passively gazing been lost, but also the original has been converted into an image so cryptic that its precise import is very difficult to grasp.

At the same time, aside from the difficulty of the inherent ambiguity of the original, there is no doubt that a truly satisfactory English translation of such a poem is impossible. Nevertheless, we can see that the "maximalist" translations of Brower and Miner :

The color of these flowers

No longer has allure, and I am left

To ponder unavailingly

The desire that my beauty once aroused

Before it fell in this long rain of time. (Brower and Miner $1967: 53$ ) 
or Rodd and Henkenius :

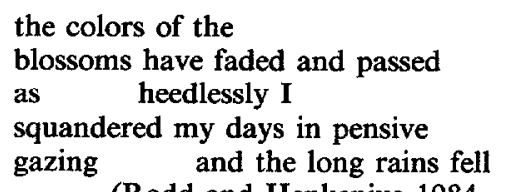

offer us a more revealing picture of the original, than the attractive but more onedimensional translations of $D$. Keene

The flowers withered,

Their color faded away,

While meaninglessly

I spent my days in the world

And the long rains were falling.

(Keene $1968: 76$ )

or McCullough :
Alas! The beauty
of the flowers has faded
and came to nothing,
while I have watched the rain,
lost in melancholy thought.
(McCullough $1985: 35$ )

(A far more subtle criticism of English translations of Ono no Komachi has been made by Okada Aiko; see Haga 1972 : 169-196.)

These reservations about the "minimalist" style of translation might seem at first slight less appropriate to the relatively briefer and plainer haiku, than to the highly conventional tanka. Yet here too one can raise doubts as to the adequacy of minimalist translations. In fact, as various writers have written, the popularity of haiku has less to do with Pound and Modernism, than with the post-war wave of enthusiasm for Japanese culture in general, and Zen in particular (see van den Heuvel 1974 : xxvii). Basho himself only began to be fully studied in the West after the war, and almost always as a "Zen poet" (see Kazuo Sato $1980: 34$.) Perhaps the leading force in the development of a "Zen" understanding of haiku was R.H. Blyth, whose works experienced a considerable vogue in the U.S. in particular. Blyth, however, was also a scholar and teacher of English Literature, and thus it is not surprising to find that his "Zen" understanding of the poems had a great deal in common with the Romantic poetics which he had imbibed as a young man :

Haiku record what Wordsworth calls those "spots of time", those moments which for some quite mysterious reason have a peculiar significance. There is a unique quality about the poet's state of feeling on these occasions ; it may be very deep, it may be rather shallow, but there is a "something" about the inner mind which is unmistakable. (Blyth 1952 : vii) 
In fact, Blyth, when explaining the relationship between "Zen" and haiku, freely cites Romantic and Victorian critics and poets; poetics is made amusingly clear when he constructs various haiku out of parts of English poems, as in :

The moon doth with delight

Look round her

When the heavens are bare. (Blyth $1952: 305$ )

The association of "Zen" with haiku itself has been criticised (see Hiroaki Sato 1983 : 126-131) ; here, however, I simply want to point out that Blyth's understanding of haiku has a great deal in common with Pound's notion of the image, and that the result is that Blyth's translations are equally "minimalist", presenting haiku as above all "poetry of the present moment". This similarity is probably best explained by the writers' common roots in Romanticism ; in Blyth's account of haiku, however, it has the predictable effect of leading Blyth to play down the powerful traditional elements of haiku, in favour of a reading based on reference to the poet's putative experience.

Blyth tends to see a literal, minimalist translation of a haiku as perfectly adequate; as the moment of insight is contained within the poem and is mystical in nature, explanation of the imagery and its association is unnecessary. This comes out well in Blyth's famous translation of Basho's haiku cited at the beginning of the paper :

The old pond

$$
\begin{aligned}
& \text { A frog jumps in - } \\
& \text { Plop! (Blyth } 1942: 217 \text { ) }
\end{aligned}
$$

As so often with "minimalist" translators, this is even briefer than the original, mizu no oto ("sound of water") being reduced to "Plop !". This is clearly a translation which emphasizes the function of the poem in recording a concrete event as vividly as possible, and which aims to evoke that event in the reader's mind. (Blyth argues that the Japanese word "oto" ("sound") has "an onomatopoeic value much nearer to "plop" ; this ignores the fact, however, that "mizu no oto" is perfectly respectable poetic diction, the phrase being used by Basho's favourite waka poet, Saigyo, for example, more than once -- see Saigyo's Sankashu nos 261 and 1026). Blyth's chief aim, in other words, is to create a "Zen poem" in English.

It is interesting to compare this with two "gendaigoyaku" (prose paraphrases in contemporary Japanese) given by two Japanese editors of Basho (my translations) :

A slow spring afternoon. The still waters of an old pond are sunk in a profound silence. Then there is the momentary sound of water as a frog plunges in, followed by a return to the original stillness. (Kon $1982: 270$ )

There is an old pond. It is a day towards the end of spring. A frog jumps into the still waters, slightly disturbing the surrounding stillness. (Imoto et al. 1972 : 103)

I cite these not to suggest that translators should necessarily expand the original at such length (a paraphrase being something different from a translation), but rather to point to the general agreement among Japanese scholars as to what the images of haiku do suggest and to the need to guide modern Japanese readers in their reading.

Perhaps the leading contemporary "Zen" translator of haiku is Lucien Stryk. His translations are, in fact, even more "minimalist" in style than those of Blyth :

Old pond,

leap-splash -

a frog. (Stryk 1985: 58) 
This could be criticised on other grounds than its sparseness (for example, the way it focuses the poem on the frog rather than the sound), but again we can see that it is guided by the desire to produce a paradoxical, startling effect on the reader, rather than the evocation of a rich, natural scene favoured by the Japanese editors cited above. This desire to startle is clearly generated by Stryk's view of haiku :

Basho strove to place his reader within an experience whose unfolding might lead to revelation, the eternal wrested from the phenomenal world. (Stryk $1985: 17$ )

Just as in Pound, but for very different reasons, it is the eccentricity, the individuality, the unfamiliarity of the perception enshrined within the haiku, rather than its dependence on tradition and convention, which are stressed. Thus, when Stryk comes to translate another of Basho's famous haiku :

\author{
kare eda $n i$ \\ karasu no tomarikeri \\ aki no kure \\ he renders it as : \\ On the dead limb \\ Squats a crow - \\ Autumn night. (Stryk 1985 : 11)
}

If we contrast the "gendaigoyaku" of the Japanese editors :

Oh a crow has settled on the branch of a withered tree from which all the leaves have fallen. How lonely this autumn dusk is. (Kon $1982: 45$ )

Looking up I notice that a crow has settled on a withered branch. Come to think of it, how appropriate such a sight is to the autumn dusk. (Imoto et al. 1972 : 62)

we can see that Stryk has converted what is to the Japanese editors a variation on the traditional theme of autumnal sadness and loneliness into a startling and angst-ridden perception of ugliness. ("Squat" and "autumn night" in particular are departures from the original.) Again, Stryk's poem would probably strike the average reader as a more interesting poem than, say, Yuasa's "maximalist" translation :

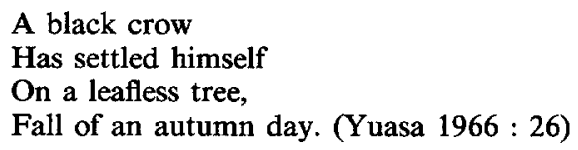

In fact, many of the things which make traditional Japanese verse valuable to the Japanese are inevitably lost in translation ; those translations which have been most successful have been so by providing interest of a very different kind to that possessed by the original. George Steiner has made the startling claim that we should accept this state of affairs :

In Pound's imitations of China, in Logue's Homer, ignorance of the relevant language is a paradoxical advantage. No semantic specificity, no particularity of context interposes itself between the poet-translator and a general, cultural-conventional sense of "what the thing is or ought to be like". Whatever the archeologists may tell us, we have come to envision antique statuary as pure white marble ; and time's erosion, having worn away the original loud colours, affirms our inspirations. (Steiner $1975: 361$ ) 
Arthur Waley, on the other hand, observed concisely that "Japanese poetry can only be rightly enjoyed in the original. And since the classical language has an easy grammar and limited vocabulary, a few months should suffice for the mastering of it" (Waley $1976: 12$ ). Those to whom neither of these solutions commend themselves, however, will continue to look to translators to provide that near impossible thing, a translation at once faithful to the original and satisfying in English. Unfortunately, it is probably impossible to convey in the translation of any one poem the relationship of the imagery and vocabulary to a rich but concentrated tradition ; this pleasure requires effort and scholarship.

\section{REFERENCES}

A.STON, W.G. (1899) : A History of Japanese Literature, Tokyo, 1972.

BASSNETT-McGUIRE, S. (1980) : Translation Studies, London and New York.

BEICHMAN, J. (1982) : Masaoka Shiki, Tokyo, 1986

BLYTH, R.H. (1952) : Haiku in four volumes, vol. 1 : Eastern Culture, Tokyo.

BROWER, R.H. and E. MINER (1961) : Japanese Court Poetry, Stanford.

BROWER, R.H. and E. MINER (1967) : Fujiwara Teika's "Superior Poems of our Time", Stanford.

CHAMBERLAIN, B.H. (1905) : Japanese Things, Tokyo, 1971.

GALT, Tom (transl.) (1982) : The Little Treasury of One Hundred Poets, One Poem Each, Princeton, New Jersey.

LANCELYN GREEN, R. and W. HOOPER, C.S. LEWIS (1976) : A Biography, London.

HAGA, T. et al. (Eds.) (1972) : Sekai no naka no Nihonbungaku (Japanese Literature in a World Perspective), Tokyo.

HEARN, Lafcadio (transl.) (1971) : Japanese Lyrics (1915), New York.

HEUVEL, Cor van den (ed.) (1974) : The Haiku Anthology, New York.

HIGGINSON, W.J. (1985) : The Haiku Handbook, New York.

HONDA, H.H. (1970) : The Shin Kokinshu, Tokyo.

HOOVER, T. (1978) : Zen Culture, New York.

IMOTO, N., N. HORI and T. MURAMATSU (eds.) (1972) : Matsuo Basho shu, Nihon kotenbungaku zenshu 41, Tokyo.

JONES, Peter (ed.) (1972) : Imagist Poetry, Harmondsworth.

KEENE, Donald (1955) : Japanese Literature: An Introduction for Western Readers, New York.

KEENE, Donald (1955) : Anthology of Japanese Literature to the Nineteenth Century, Harmondsworth, 1968. KODAMA, S. (1984) : American Poetry and Japanese Culture, Hamden, Connecticut.

KON, E. (ed.) (1982) : Basho kushu, Shincho Nihon kotenshusei 51, Tokyo.

McCULLOUGH, H.C. (transl.) (1985) : Kokin Waskashu: The First Imperial Anthology of Japanese Poetry, Stanford.

MINER, E. (1958) : The Japanese Tradition in British and American Literature, Princeton, New Jersey.

MINER, E. (ed.) (1985) : Principles of Classical Japanese Literature, Princeton, New Jersey.

MIYATA, H. (ed.) (1981): The Ogura Anthology of Japanese Waka, Tokyo.

OZAWA, M. (ed.) (1971) : Kokinwakashu, Nihon kotenbungaku zenshu 7, Tokyo.

PONDROM, Cyrena N. (1974): The Road from Paris : French Influence on English Poetry 1900-1920, Cambridge.

REXROTH, Kenneth (transl.) (1964) : One Hundred Poems from the Japanese (1955), New York.

REXROTH, Kenneth (1970): With Eye and Ear, New York.

REXROTH, Kenneth (1973) : "The Influence of Classical Japanese Poetry on Modern American Poetry", The Elastic Retort : Essays in Literature and Ideas, New York.

RIMER, J. Thomas and Robert E. MORRELL (1975) : Guide to Japanese Poetry, Boston.

RODD, L.R. with M.C. HENKENIUS (transl.) (1981) : Kokinshu : Ancient and Modern Collection of Poems, Tokyo and Princeton, New Jersey.

SATO, Hiroaki (1983) : One Hundred Frogs : from Renga to Haiku in English, New York and Tokyo.

SATO, Kazuo (1980): "Gaikokujin no mita Basho" ("Basho as Seen by Foreigners"), in R. Ogata (ed.), Basho Hikkei, Tokyo, pp. 29-34.

STEINER, G. (ed.) (1966) : The Penguin Book of Modern Verse Translation, Harmondsworth.

STEINER, G. (1976) : After Babel : Aspects of Language and Translation, Oxford.

STRYK, Lucien (transl.) (1985) : On Love and Barley : Haiku of Basho, Harmondsworth.

SUllivaN, J.P. (ed.) (1970) : Ezra Pound: A Critical Anthology, Harmondsworth.

WALEY, A. (1919) : Japanese Poetry : the Uta, London, 1976.

YUASA, N. (transl.) (1966) : Basho: the Narrow Road to the Deep North and other Travel Sketches, Harmondsworth. 